\title{
ANTI-SOLAR STUDY OF ETHANOLIC EXTRACT OF LEAVES CASSIA FISTULA
}

\author{
Varsha Gharge, Tulashiram Lokhande \& Shobha Hadpad* \\ Gourishankar Institute of Pharmaceutical Education \& Research, Limb, Satara, India-415015
}

\begin{abstract}
Objective: The present study aimed at the phytochemical examination and anti-solar activity of Cassia Fistula (leaf) Ethanolic extract has more Flavonoid content based on this chemical substance photo protective activity was evaluated using UV visible spectrophotometry, where the method is diffused transmittance and the range of UV-visible about 200-400nm.

Methods: The pulverized dried Cassia Fistula was extracted with ethanol using soxhlet apparatus. Ethanolic extract were filtered \& evaporated to dryness. The photo protective activity was evaluated by using UV visible spectrophotometer, where the method it is diffused transmittance and the range of UV-visible about 200-400nm.

Results: The UV scanning absorption spectra of the extract showed very strong absorption at $0.265 \mathrm{~A}$ with $\lambda$ max at $268 \mathrm{~nm}$.

Conclusion: The extract has an ability to absorb in the entire UV range.
\end{abstract}

Keyword: UV rays, Cassia Fistula, Flavonoid content, ethanolic Extract, Anti-Solar

Article Info: Received 05 Sep, 2018; Review Completed 03 Oct 2018; Accepted 05 Oct 2018; Available online 15 Oct 2018

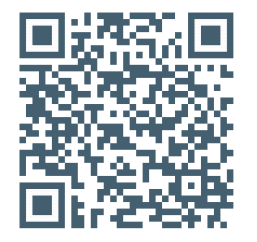

Cite this article as:

Gharge V, Lokhande T, Hadpad S, Anti-solar study of ethanolic extract of leaves Cassia fistula, Journal of Drug Delivery and Therapeutics. 2018; 8(5-s):232-234 DOI: http://dx.doi.org/10.22270/jddt.v8i5-s.1964

\section{*Address for Correspondence:}

Hadpad Shobha, Research Scholar Student, Department of Pharmacognocy and phytochemistry, Gourishankar Institute of Pharmaceutical Education \& Research, Limb, Satara, Maharashtra, India-415015.

\section{INTRODUCTION}

Ultra violet radiation (UVR) exposure to skin causes skin disorder such as squamous cell aging immune depression of skin and photodermatose. In recent year herbs have been used in the medicines to treat different skin disease. When skin surface absorb ultraviolet radiations free radicals or reactive oxygen species are produced having adverse effect such as sunburns, wrinkles, lower immunity against infection premature aging and cancer hence protective and preventions are required from ultra violet radiation. ${ }^{1-4}$. The UV radiations are categories in the three categories as such UV-C(200-280nm), UV-B(280-320nm), UV-A(320$400 \mathrm{~nm})$ from above three categories of UV radiation , $\mathrm{UV}-\mathrm{C}$ radiation can cause severe biological damage to skin as compared to UV-B and UV-A radiation. But UV-C radiations are filtered by the ozone layer, so $\mathrm{UV}-\mathrm{B}$ and UV-A radiation is currently the reason for causing skin cancer, so as to avoid this sunscreen agents are used which act as a protective agents against harmful UV radiations ${ }^{5-12}$. Cassia fistula L. (Caesalpinioideae), a very common plant known for its medicinal properties is a semi wild Indian Labernum Known as the golden shower tree. It has great therapeutic implication in India system of medicine. The extracts derived from different parts of this plant have anti-bacterial, antipyretics, analgesic, antiinflammatory and hypoglycemic properties and are used in the treatment of various disorders such as haematemesis, rheumatism, skin diseases, eye and liver ailments It is also one of the ingredients of the preparations known as pilex, Purian for piles and detoxifier respectively ${ }^{5}$. Phytochemical investigation of crude plant extracts shown the presences of bioactive principles in the plant parts like flowers, roots, fruits, seeds, leaves and barks etc. Phytochemical are non-nutritive plant chemicals that have protective or disease preventive properties. Various parts of these plants are known to be important sources of secondary metabolites mainly phenolic 
compounds such as epicatechin, procyanidin, biflavonoids, rhein glycosides, from the leaves ${ }^{13-18}$

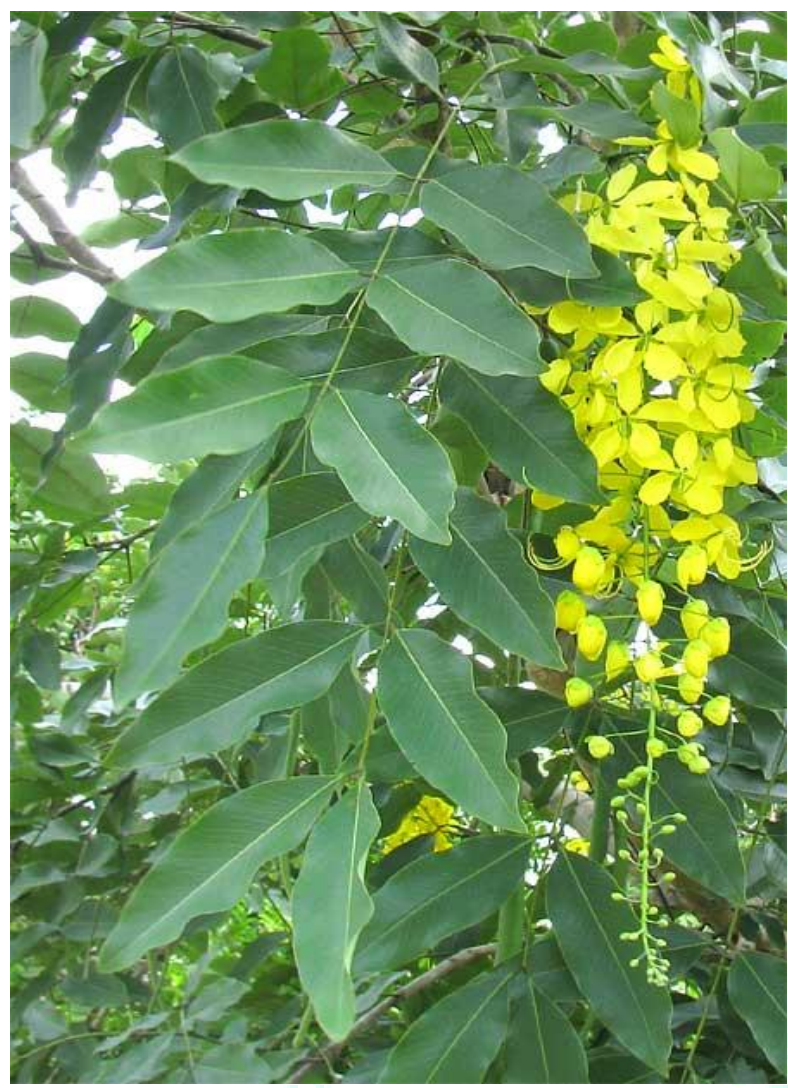

Figure 1: Whole Plant of Cassia Fistula

\section{MATERIAL AND METHODS}

The leave Cassia Fistula $L$ was collected from satara, Maharashtra, washed properly and shade dried. The dried leaves powdered and used for the extraction purpose. The specimens were identified by in the department of botany Y.C. college satara.

\section{Extraction Method:}

The pulverized dried leaves Cassia Fistula $L$ were extracted with ethanol using soxhlet Apparatus. Ethanol extract were filtered \& evaporated to dryness. 19-21

\section{Photochemical Examination:}

The general flavonoid identification tests were performed on the extract.

Test 1: To dry extract, add $5 \mathrm{ml}$ of $95 \%$ ethanol, few drop of concentrated hydrochloric acid and $0.5 \mathrm{~g}$ of magnesium turning. The finally pink color observed. (Shinoda test)

Test 2: To a small quantity of extract, add lead acetate solution, it shows yellow colored Precipitate is formed.

\section{Anti-solar activity:}

\section{Preparation of sample:}

The sample preparations were carried out by $10 \mathrm{mg} \%$ $\mathrm{w} / \mathrm{v}$ concentration dissolving into the $100 \mathrm{ml}$ of distilled water $(10 \mathrm{mg} / 100 \mathrm{ml})$. Evaluation of anti-solar activity the UV absorption spectrum for extract was obtained in range of $200-400 \mathrm{~nm}$ using Double beam UV-Vis Spectrophotometer Model Shimadzu-1700.

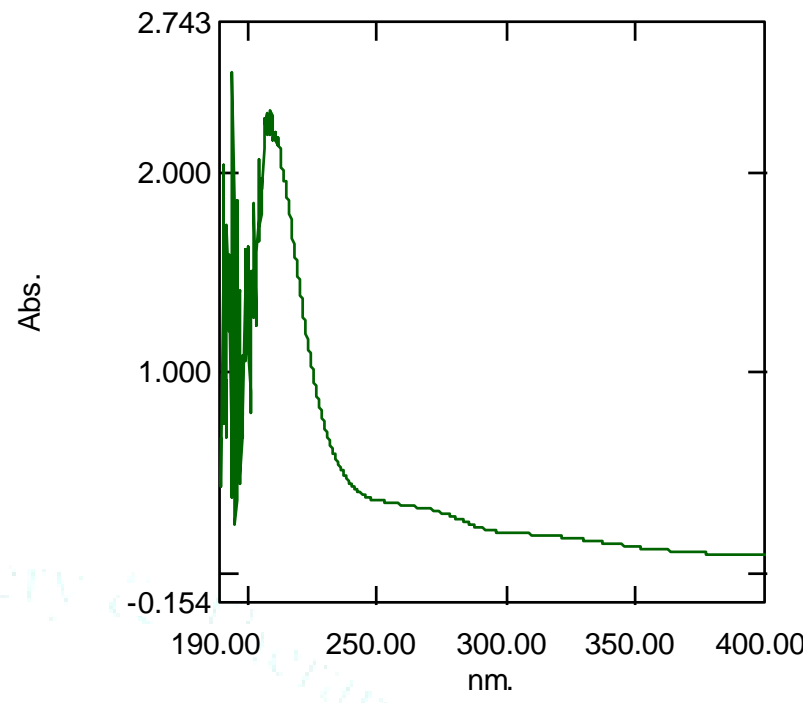

Figure 2: Following figure indicate computerized display reading of absorption spectra of the extract which is directly taken from spectrophotometer.

\section{RESULTS}

The UV scanning absorption spectra of the extract showed very strong absorption at $0.265 \mathrm{~A}$ with $\lambda$ max at $268 \mathrm{~nm}$. The graph extract also showed a plateau in range of $300-400 \mathrm{~nm}$ with moderate absorbance of $\sim 0.35-0.13$

\section{DISCUSSION}

Quantitative investigation showed the presence of flovonoids in the extract. Flvonoids are well known for their pharmacological activities. It absorbs light and helps to protect photosensitive substances in leaves. Absorption of UV radiation is the main characteristics feature of the flavonoids. The results showed strong to moderate absorption of UV radiation and this ability is due to the presence of flavonoids.

\section{CONCLUSION}

The ethanolic extract of leaves have ability to absorb UV radiation. The proved anti -solar activity of the plant shows its importance and prophylactic utility in anti-solar formulation. This will be a better cheaper and safe alternative to harmful chemical sunscreens that used nowadays in the industry. 


\section{REFERENCES}

1. Panthari $\mathrm{P}, \mathrm{Kharkwal} \mathrm{H}$, formulation and in vitro evaluation of sun protection factor of myricanagi ethyl acetate extract sunscreen cream. IJAPR 2013; 4(10):2401-2406.

2. Gupta P, UV absorbing properties of some plant derived extract RJCES 2013; 1(2):34-36.

3. More B, Sakharwade S, Tembhurne S, Sakarkar D, evaluation of sunscreen activity of cream containing leaves extract of butamonasperma for topical application. IJRCS 2013; 3(1):1-6.

4. Barbalho S, Flavia M, Machado F, Goulart A. pasidumguajava (guava): a plant of multipurpose medicinal application. Medicinal \& aromatic plants 2012; 1(4):1-6.

5. Gharge V, Gore M, Ahire P, Ghorpade P, Yadav A. study of ethanolic extract of leaves of murrayakoenigi as an antisolar. IJIPSR, 2017; 5(04):1-6.

6. Gore M, Gharge V, Ahire P, Ghorpade P, Yadav A. study of methanolic extract of leaves of tridexprocumbens as an antisolar. EJPMR 2017; 4(9):306-308.

7. Gore Meghana, Gharge Varsha, Ahire Pallavi, Ghorpade Pranita, Bhandwalkar Omkar, Dr. Yadav Adhikrao, Study of Methanolic Extract of Leaves of Tridax Procumbens As An Anti-Solar. European Journal of Pharmaceutical and Medical Research 2017; 4(9):1-3.

8. Gharge Varsha, Gore Meghana, Ahire Pallavi, Ghorpade Pranita, Dr. Yadav Adhikrao, Study of Ethanolic Extract of Leaves of Murraya Koenigii As An Anti-Solar. International Journal of Innovative Pharmaceutical Sciences and Research 2017; 5(4):99-104.

9. Gharge V, Study of Methanolic Extract of Leaves Nyctanthes Arbortristis as an Anti-Solar. World Journal of Pharmaceutical Research 2017; 6(13):893-898.

10. Gore Meghana \& Gharge Varsha., Study of Aqueous Extract of Black Tea as an Anti-Solar. International Research Journal of Pharmacy 2017; 8(11):72-73.

11. Gharge VG, Ghadge DM, Shelar PA and Yadav AV. Importance of Pharmacognostic study of medicinal plants
Calotropis gigantea (Linn.): A review. Int J Pharmacognosy 2017; 4(11):363-71

12. Gharge V, Study of Methanolic Leaves Extract of Curcuma longa as an Anti-solar. Current Research in Pharmaceutical Sciences 2017; 07 (03):87-90.

13. Prashanth Kumar V, Chauhan NS, Padh H and Rajani M. Search for Antibacterial, Anti-fungal agents from selected Indian Medicinal Plants. J Ethanopharmacol. 2006; 107:182188.

14. Hahorun T, Neergheen VS, Aruoma OI. Phytochemical constituents of Cassia fistula African J Biotech 2005; 4:1530-1540.

15. Duraipandiyan V, Ignacimuthu V. Antibacterial Activity on Medicinal Herbs J Ethanopharmacol. 2007; 1:590-594.

16. Sangeetha SN, Zuraini Z, Sashidharan S, Sunaini S. Calculations for Molecular Biology and Biotechnology J Mol Biol Biotech. 2008; 1:1-4.

17. Agrawal SS and Paridhavi M. Clinically useful herbal drugs. Ahuja Publishing Home. 2005; 281-282.

18. Kaji NN, Khorana ML and Sanghavi MM. Studies on Cassia fistula Linn. Indian J Pharma 1968; 30:8-11

19. Gharge V.G., Ms. Shelar P.A. et al. Pharmacognostic Standardization, Phytochemical Evaluation and Antimicrobial Activity of Leaf Extracts of Tridax Procumbens. International Journal of Universal Pharmacy and Bio Sciences 2016; 5(6):133-145.

20. Gharge V G, Shelar P A. et al. The Pharmacognostical, Phytochemical and Antimicrobial Studies of Leaves Cassia Auriculata Linn. Research Journal of Pharmacognosy and Phytochemistry (RJPP) 2017; 9(2):1-8.

21. Shelar P.A, Ms. Gharge V.G. et al. The Pharmacognostical, Phytochemical and Antimicrobial Studies of Leaves Extracts of Urena Lobata Linn. Current Research in Pharmaceutical Sciences 2017; 07(02):40-49. 